\title{
1. Human rights inflation in the European Union
}

\section{Matej Avbelj}

\section{FROM YUGOSLAVIA TO THE EUROPEAN UNION AND BACK?}

In my youth, I lived in a country where it was really easy to become a millionaire. Every month, sometimes even every week, new zeroes were added to the banknotes of our national currency. While I was thus, as a child, very proud to hold increasing sums of money in my hands, I did not realize that my family and I were, in fact, getting poorer as time passed. With every zero added, the then Yugoslav dinar could actually buy fewer commodities. The more money I had nominally, the lower the money's purchasing power and, hence, its real value. To live its socialist dream, for years Yugoslavia had to endure hyperinflation. Eventually, as is well known, the dream was over and the country had to wake up to a nasty reality, which everyone then and now wished was just a bad nightmare.

I wish the same does not happen to the Rechtsgemeinschaft of the European Union ${ }^{1}$ in which we nowadays live together. There are, unfortunately, not few parallels that could be drawn between the then Yugoslavia and the present EU, but for the purpose of this chapter I would like to dwell on a single metaphorical one. As Yugoslavia's price for its socialist dream was monetary hyperinflation, the European Union's price for its desired polity legitimacy appears to be a human rights inflation. It has thus been submitted that:

Greater emphasis on fundamental rights [...] contributes to the consolidation of a set of distinctly European values, thereby reinforcing the sense of identity

1 The term was coined by Walter Hallstein. For an in-depth discussion: see F.C. Mayer, 'Europa als Rechtsgemeinschaft' [2005] 8 WHI Paper, available at: http://whi-berlin.de/documents/whi-paper0805.pdf. 
and community uniting the peoples of Europe, which in turn strengthens the Union's political legitimacy. By structuring the legal and political discourse around the culture of rights, the EU institutions not only boost their credibility, simultaneously placing themselves closer to citizens, but also contribute to the creation of a European public sphere. ${ }^{2}$

And yet, it appears that the more the EU has formally and symbolically invested in human rights, the lower is the degree of actual human rights protection in the EU and its states. In other words, while the value of the EU human rights currency has grown in nominal terms, its real purchasing power seems to be in decline. This creates a perverse effect that cannot be only likened to my childish impression of getting richer by way of possessing nominally higher sums of money - it is even worse.

With the inflation of human rights in the EU, an individual is encouraged in her belief that she has more rights and additional fora to ensure their better protection. The expectations are thus made high. But, if and when these high expectations do not materialize in practice, in particular individual cases, the disappointment that follows is necessarily grave. When more human rights on paper lead to less protection in practice, the real value of human rights inevitably starts falling. Common people lose faith in human rights, which also and simultaneously leads to a decline of a real commitment of institutional stakeholders to them. Human rights then risk becoming a dead letter, a useful means for window-dressing and a handy ideological tool for justifying political deeds which have very little in common with the properties of a well-ordered society, whose part and parcel human rights protection necessarily is.

Against this backdrop, the chapter will argue that when it comes to human rights protection in the European Union, less might be more. The inflationary trend of investing nominally into human rights poses a risk of being self-defeating and should be stopped. Instead, human rights have to be taken seriously in practice by the competent actors on the level closest to where human rights violations actually occur. This would require theoretical, doctrinal and institutional adjustments across the European constitutional space. Some of those will be presented in the conclusion of this chapter. However, before getting there, it is first necessary to understand how and why the EU embarked on its human rights inflationary route, as well as, secondly, why exactly this inflation causes harm to the value of human rights protection.

2 F. Ferraro, J. Carmona, Fundamental Rights in the European Union (EPRS, European Parliament, 2015) 24. 


\section{FIVE STEPS TO HUMAN RIGHTS INFLATION IN THE EUROPEAN UNION}

The development of human rights protection in the European Union has travelled through five stages. As was documented in great detail elsewhere, initially human rights protection was not part of the then Community law. ${ }^{3}$ Due to their limited material scope and narrow economic objectives, the three European Communities were not expected to engage in human rights violations. There was thus no perceived functional demand for human rights norms to be included in the founding treaties. Moreover, the Council of Europe, tasked with protection of human rights in Europe, had been created before the emerging European Communities. Following the division of labor, this enabled the latter to focus exclusively on their economic prerogatives. Finally, after WWII, human rights were generously inscribed in the national constitutions and were considered a top priority of domestic institutions, in particular of the newly formed constitutional courts.

It was precisely this fact that initiated a transition of human rights protection to the second stage. Following the ECJ's landmark decision inaugurating the principle primacy of EU law, ${ }^{4}$ the national law, including national constitutions densely populated with human rights provisions, in case of conflict had to give way to EU law, which contained no reference to human rights protection. Not unsurprisingly, national constitutional courts, with the German Federal Constitutional Court acting as a flag-bearer, resisted that construction of primacy and threatened to put this leading principle of EU law and the latter's overall autonomy in question:

as long as the integration process has not progressed so far that the Community law would also embody a catalogue of fundamental rights decided on by a parliament and of settled validity which would be adequate in comparison with the catalogue of fundamental rights contained in German Constitution. ${ }^{5}$

3 J.H.H. Weiler, 'Methods of Protection: Towards a second and third generation of protection' in Cassese, Clapham, Weiler (eds.), Human Rights and the European Community: Methods of Protection (1991) 555.

4 Case C-6/64, Costa v. Enel, [1964] ECR 585, [1964] 3 C.M.L.R. 425.

5 See Case 2 BvG 52/71, Internationale Handelsgesellschaft $m b H \quad v$. Einfuhr- und Vorratstelle für Getreibe und Futtermittel, [1974] 2 C.M.L.R. 540. German Bundesverfassungsgericht (Federal Constitutional Court) in this case, better known as Solange I, reserved for itself the right to determine Community 
In the absence of a textual basis for EU human rights protection, the initially reluctant ECJ6 was pressed to create the EU's own standards of human rights protection literally ex nihilo. In a chain of cases ${ }^{7}$ the Court developed the unwritten standard of human rights protection in the European Union pursuant to which:

Fundamental rights form an integral part of the general principles of law, observance of which [the Court] ensures. For that purpose the Court draws inspiration from the constitutional traditions common to the Member States and from the guidelines supplied by international treaties for the protection of human rights on which the Member States have collaborated or of which they are signatories. [...] The European Convention on Human Rights (ECHR) has special significance in that respect. ${ }^{8}$

Naturally, as expected and required by the national constitutional courts this judge-made EU standard of human rights protection was made binding on the EU institutions, which had previously, unlike their national counterparts, not been bound by the requirements of human rights protection. However, this changed in stage three of the development of EU human rights protection. If stage two marked the invention of EU standard of human rights protection, stage three concerned the extension of its personal scope of application and the entrenchment of the material scope of application. ${ }^{9}$

With regard to the former, the ECJ now held that not only the EU institutions but also states are bound by the EU standard of human rights

rule which would conflict with a guarantee of basic rights in the German Constitution inapplicable in Germany.

6 Case C-1/58, Stork \& Co. v. High Authority of the European Coal and Steel Community, [1959] ECR 17. In this case ECJ refused to engage in judicial review based on fundamental human rights by claiming that it was required only to ensure that the law is observed in the interpretation and application of the treaty and of rules laid down for implementation thereof, and that it was normally not required to rule on provisions of national law. There was namely a contention that High Authority by adopting its decision infringed principles of German constitutional law. It is obvious from the wording of this decision that ECJ understood the protection of human rights to be in the exclusive domain of the member states.

7 Case C-29/69 Stauder [1969] ECR 419; Case C-11/70 Internationale Handelshesellschaft [1970] ECR 1125; Case C-4/73, J. Nold, Kohlen-und Baustoffgrosshandlung v. Commission, [1974] ECR 491, 507.

8 Case C-4/73 J. Nold, Kohlen- und Baustoffgrosshandlung v. Commission of the European Communities, supra n. 7.

9 See also Weiler, supra n. 3, 555. 
protection when they implement $\mathrm{EU} \mathrm{law}^{10}$ or avail themselves of a derogation provided by the treaties. ${ }^{11}$ This case law was subsequently apparently circumscribed by the EU Charter of Fundamental Rights, which was explicitly made binding on the member states only when they implement EU law. ${ }^{12}$ However, the ECJ glossed over the language of the Charter and sought to entrench its previous case law, insisting that the Charter and hence the EU standards of human rights protection are binding on the member states whenever they act within the scope of EU law. ${ }^{13}$

The extension of personal scope of application of the EU standard of human rights protection developed in parallel with attempts of entrenching the EU's own standard of material scope of application. The ECJ has consistently claimed that the EU standard of human rights protection, while inspired by the national constitutional traditions and international human rights instruments, is ultimately its own autonomous standard. ${ }^{14}$ In the name of unity and effectiveness of EU law, the ECJ rejected the attempts made by the national constitutional courts to claim exemptions from EU law by asserting higher national constitutional standards of human rights protection. ${ }^{15}$ Not only did this ignite a largely academic maximum-minimum standard debate, ${ }^{16}$ it again agitated the national constitutional courts. While in the 1970s they had, in principle, been made content with the ECJ's approach to human rights protection, the ECJ's later uncompromising stance on primacy and autonomy of EU law came across as a threat to the preservation of the national constitutional

\footnotetext{
10 Case C-5/88, Wachauf v. Germany, [1989] ECR 2609.

11 Case C-260/89, Elliniki Radiofonia Tileorasi - Anonimi Etairia (ERT-AE)

v. Dimotiki Etairia Pliroforissis, 1991-6 [1993] ECR I-2925.

12 Charter 51/1.

13 Case C-617/10, Akerberg Fransson.

14 Case 44/79, Hauer v. Land Rheinland-Pfalz [1979] ECR 3727.

15 Case C-399/11 Melloni.

16 L.F.M. Besselink, 'Entrapped by the maximum standard: on fundamental rights, pluralism and subsidiarity in the European Union' (1998) 35 C.M.L.R. 629, 636; contra J.H.H. Weiler, 'Fundamental rights and fundamental boundaries: on standards and values in the protection of human rights' in Neuwahl, Rosas (eds.), The European Union and Human Rights 51, 52. For an overview see also M. Avbelj, 'European Court of Justice and the question of value choices', (2004) Jean Monnet Working Paper 06, available at: http://www. jeanmonnetprogram.org/archive/papers/04/040601.pdf.
} 
identity lato sensu. ${ }^{17}$ Combined with the fact that the EU standard of human rights protection was judge-made, unwritten, which detracted both from its legitimacy as well as from the expectations of legal certainty and predictability, ${ }^{18}$ human rights protection in the European Union came under strain again. It was in need of further mending and improvement.

This took place in stage four that witnessed a set of treaty and institutional developments in the field of EU human rights protection. Starting in the 1970s the then Community institutions attempted to back up the ECJ's nascent human rights jurisprudence by a number of soft-law mechanisms. ${ }^{19}$ The first legally binding reference to the EU human rights protection was inserted in the Treaty of Maastricht ${ }^{20}$ and the Treaty of Amsterdam later explicitly proclaimed that the Union is founded on the principles of liberty, democracy, respect for human rights and fundamental freedoms, and the rule of law, principles which are common to the member states. ${ }^{21}$ In this way the ECJ's human rights jurisprudence received also the official member states' political endorsement in the form of the treaty change. The momentum was hence built and the road paved to the EU's own fully-fledged written human rights catalogue. A comprehensive EU Charter of Fundamental Rights was solemnly proclaimed in 2000 and made binding in 2009 as a constitutive part of the Treaty of Lisbon. Last but not least, the formal system of human rights protection ensured by the ECJ has been supplemented by an informal one, exercised by the EU Ombudsman, and the EU Fundamental Rights Agency was created in 2007 too. Its task is to offer evidence-based advice to the competent EU institutions and hence contribute to strengthening the EU as a community of values.

17 M. Avbelj, 'European Court of Justice and the question of value choices', (2004) Jean Monnet Working Paper 06, available at: http://www.jeanmonnet program.org/archive/papers/04/040601.pdf.

18 Ibid.

19 These included the 1973 Declaration on European Identity; a 1977 Joint Declaration on Fundamental Rights; a 1984 draft European Union Treaty by the European Parliament; a 1989 Resolution on Fundamental Rights and a Declaration of Fundamental Rights and Freedoms. For an overview see Ferraro, Carmona (n. 2) 6-7.

20 Art. F.2: The Union shall respect fundamental rights, as guaranteed by the European Convention for the Protection of Human Rights and Fundamental Freedoms signed in Rome on 4 November 1950 and as they result from the constitutional traditions common to the member states, as general principles of Community law.

21 Art. 6 TEU Amsterdam. 
Eventually the EU thus fully met the Solange conditions set by the German Constitutional Court almost 40 years ago. Nevertheless, one brick was still missing in the EU human rights edifice: a full accession to the European Convention of Human Rights. While the latter has been unilaterally incorporated as part and parcel of EU human rights standard, the EU was not formally a member of the Convention. As a result, it was ineligible to stand either as a plaintiff or as a defendant before the ECtHR. The fifth stage of EU human rights development was thus devoted to the accession of the EU to the ECHR. As the first attempt failed due to the lack of EU competence for accession, ${ }^{22}$ the Treaty of Lisbon closed that competence gap by mandating the Union to accede to the ECHR. However, the second accession attempt was not successful either. For the lack of sufficient guaranties for the autonomy and primacy of EU law, the ECJ found the long and carefully negotiated Accession Agreement incompatible with the Lisbon Treaty. ${ }^{23}$ The legal and political limbo that ensued has been managed through a previously reached, provisional, formal and informal judicial dialogue conducted in the spirit of mutual recognition between the ECJ and the ECtHR. ${ }^{24}$

It follows from this brief overview of the development of EU human rights protection that the EU nowadays boasts of a fully-fledged mechanism for human rights protection. This draws on three sources: the ECJ's jurisprudence, pursuant to which human rights are to be protected as general principles of EU law; the EU Charter of Fundamental Rights which is the EU's written catalogue of rights; and the ECHR, which is another written catalogue of rights, so far, and pending accession to the Convention, only unilaterally borrowed from the Council of Europe. These three sources of human rights protection make up the EU material standard of human rights protection, whose personal scope encompasses not only the acts of EU institutions lato sensu, but also the member states whenever their actions fall within the scope of EU law.

From the perspective of the individual this means that she can formally avail herself of at least three systems of human rights protection. There is primarily the national system of human rights protection with the national constitutions and constitutional courts standing at its apex. Its purpose is to protect the individual against her own state. Secondly, there is the just described EU system of human rights protection, which

22 ECJ Opinion 2/94 on the Accession of the EC to the ECHR.

23 ECJ Opinion 2/13 on the Accession of the EU to the ECHR.

24 S. Morano-Foadi, S. Andreadakis, 'The convergence of the European legal system in the treatment of third country nationals in Europe: The ECJ and ECtHR Jurisprudence' (2011) 4 European Journal of International Law 1071. 
endows individuals with the rights against the EU institutions, but also, at least indirectly, but sometimes by way of a national incorporation of the Charter, ${ }^{25}$ also directly against the national institutions. Finally, as a subsidiary system of human rights protection, there is also the ECHR, which shields individuals against national authorities as well as, albeit still indirectly, against supranational authorities. In material terms the standards of human rights protection are thus national, supranational and international. Their existence is simultaneous and the material scope of application is not clearly delineated between them. While it is clear that the ECHR objective is to ensure the common minimal standard of human rights protection in Europe, which the member states cannot fall below but can always go beyond, the same principle does not underlie the relationship between the national and supranational standards. ${ }^{26}$ Finally, as an individual can thus rely on many material sources of human rights protection that diverge in terms of their scope and intensity, she can also argue these standards in many fora. There are national ordinary courts and typically also constitutional courts. There is the Court of Justice of the European Union and finally the European Court of Human Rights (ECtHR). All are to be, at least ideally, human rights courts that ensure the highest level of protection to each and every individual.

While the EU thus undoubtedly made progress in human rights protection, this evolution has never been received with a unanimous approval. From the very beginning the motive behind the emergence of EU human rights protection has been disputed. The mainstream view has held that, like the rest of the ECJ's landmark cases, its human rights jurisprudence was intended to improve the status of an individual in EU law, to genuinely protect her rights, both against the EU institutions as well as against non-complying member states. ${ }^{27}$

Others, on the other hand, disputed that the Court's jurisprudential moves were essentially an attempt at its own self-aggrandizement and continuous encroachment on the residual competences of the member states. ${ }^{28}$ Pursuant to this critical view, the individuals and their rights

25 Decision of the Austrian Constitutional Court U 466/11-18, U 1836/1113, 14 March 2012, making the EU Charter of Fundamental Rights a material standard for the review of constitutionality in Austria.

26 Avbelj supra n. 17.

27 Weiler supra n. 3.

28 For an early critical approach, see, R. Hjalte, On Law and Policy in the European Court of Justice: A Comparative Study in Judicial Policymaking (Nijhoff, Kluwer, 1986). 
have been largely instrumental to the grander institutional, indeed political objectives of the integration. In other words, human rights in the EU have not been developed as a self-standing objective but as a means for the achievement of other ends. The EU human rights protection was thus introduced to save the principles of primacy and autonomy of EU law from the attacks of national courts. ${ }^{29}$ Once this has been achieved, human rights in the Union have been relied upon to quell the concerns surrounding the rising democratic deficit. As we have seen, they have been put forward as a source of legitimacy of the Union's institutions and as a catalyst for the European identity of EU citizens.

However, even without siding with these critical views, it needs to be admitted that human rights protection in the Union, while well intended, appears to be a victim of a self-perpetuating human rights rhetoric. This professes that the more there are human rights catalogues and human rights authorities, the better the guarantees for human rights protection. Human rights protection is thus in a positive correlation with the number of human rights documents and authorities. On this account, the inflation of human rights is a positive phenomenon that ought to be welcomed. Under this scenario human rights do not play an instrumental role; they are not a means to some other end. They are an end of itself, but literally so. Human rights protection becomes about the protection of human rights: as a concept, as a rhetoric, perhaps even as an ideology, rather than the protection of individuals as subjects and bearers of human rights.

Which of these views is correct or at least more persuasive? The answer to this question depends, at least in part, on the performance of the EU human rights regime in practice. Has the described material and formal inflation of human rights protection in the European Union in fact contributed to the better human rights protection of individuals in practice? I, for one, would certainly wish that to be the case, but several pieces of empirical evidence point to the opposite.

29 J. Coppel, A. O'Neill, 'The European Court of Justice: Taking rights seriously?' [1992] 29 C.M.L.R. 669. For a rebuff, see, J.H.H. Weiler, Nicolas J.S. Lockhart, "Taking rights seriously" seriously: The European Court and its fundamental rights jurisprudence - part I' [1995] 32 C.M.L.R. 51-94. 


\section{THREE NEGATIVE EXAMPLES OF EU HUMAN RIGHTS INFLATION IN PRACTICE}

\subsection{EU Accession to the European Convention on Human Rights}

I will focus on three case studies in chronological order. The first concerns the EU accession to the ECHR. Considered as a human rights step of systemic importance, it has been on the agenda for years, but it still has not been completed. A lot of diplomatic, political and legal efforts have been invested in the EU's accession to the ECHR, both on the level of the Council of Europe as well as in the Union itself. A lot of energy has thus been used, so far unproductively, and even more academic ink has been spilt. ${ }^{30}$ Yet other than serving the grander objectives of the EU legitimacy, its constitutional and systemic coherence, etc., would the accession of the EU to the ECHR bring any meaningful change in the protection of individual rights in the Union? Admittedly, this effect is hard to foresee. With regard to the ECJ's jurisprudence, nothing will change. The ECHR is already now a constituent part of the EU human rights standard. Its role is fully recognized and the ECJ contributes to its status of a living human rights document by unilaterally following the jurisprudence of the ECtHR.

The accession of the EU to the ECHR would make the Convention formally binding on the Union institutions and, in so doing, put the ECtHR formally in charge of the review of their acts. However, it can be anticipated, also following the language of the Accession Agreement, that the number of such cases would and should be limited. But even if the number was huge, that would be of little avail to the individuals and their rights. The fact is the ECtHR has long been a victim of its own success. The Court has for years drawn many more applications than it has been able to rule upon. In illustration, in 2011, which was probably the most critical year in the Court's history, more than 151000 cases were pending before the Court, while the latter managed to decide roughly more than

30 See, for example, T. Lock, 'EU Accession to the ECHR: Implications for the Judicial Review in Strasbourg', (2010) 35 European Law Review 777; C. Eckes, 'EU Accession to the ECHR: Between Autonomy and Adaptation', (2013) 76 Modern Law Review 254-285; P. Craig, 'EU Accession to the ECHR: Competence, Procedure and Substance' (2013) 36 Fordham International Law Journal 1114; D. Halberstam, “'It's the autonomy, stupid!" A Modest Defense of Opinion 2/13 on EU Accession to ECHR, and the Way Forward' (2015) 16 German Law Journal 105. 
1500 cases on the merits. ${ }^{31}$ The Court was thus forced to start a reform process, which was principally aimed at reducing its huge backlog and managing its docket. ${ }^{32}$ The effects can be already identified. The number of cases which reach the judicial formation of the Court has decreased drastically ${ }^{33}$ thanks to the Court's "high filtering capacity". ${ }^{34}$ In 2015 around 73000 applications were lodged at the Court's registry. Most of them have been dismissed on procedural grounds, of which more than 40 percent have never reached the judges as they failed to meet the administrative requirements. Only 5 percent of the cases have been decided on the merits, and among those only a third were decided in individuals' favor. ${ }^{35}$ This means that among thousands of applications that reach the ECtHR every year, only 5 percent are admitted by the Court and the requested remedy is awarded in fewer than 2 percent of the cases.

From the individual's perspective, the ECtHR thus provides only a very distant opportunity for human rights protection. By trying to clear its backlog, this opportunity is inevitably subject to further decline as the Court will have to strengthen its filtering capacity. As a result, the gap between the individuals' human rights expectations, deriving from and being fueled by the culture of rights, and their actual capacity to have their rights defended is growing. If we add to this that the ECtHR's judicial authority has been severely undermined by the states' reluctance to enforce judgments rendered against them, ${ }^{36}$ so that even those individuals who have been awarded a remedy ultimately cannot enjoy it, the ECtHR outlook for human rights protection of individuals is even gloomier. Against this backdrop, it is hard to argue persuasively about the crucial, systemic importance of the accession of the EU to the ECHR. For if the latter cannot be expected to contribute meaningfully to human rights protection, then the accession to ECHR is either not necessary or is

31 ECHR Statistics 2015, http://www.echr.coe.int/Documents/Stats_analysis_ 2015_ENG.pdf.

32 Steering Committee for Human Rights, report on the longer-term future of the system of the European Convention on Human Rights, http://www.coe.int/ t/dghl/standardsetting/cddh/reformechr/CDDH(2015)R84_Addendum\%20I_ENFinal.pdf.

33 In 2011 there were still 151600 cases pending before the judicial formation, in 2015 this number fell to 64850 applications.

34 DH-GDR (2015) R9 Addendum, 33.

35 http://www.echr.coe.int/Documents/Stats_violation_2015_ENG.pdf.

36 K. de Vries, 'Parliamentary Assembly of Council of Europe: Report: Implementation of judgments of the European Court of Human Rights', http:// assembly.coe.int/nw/xml/XRef/Xref-DocDetails-EN.asp?fileid=22005. 
motivated by other reasons not directly related to individuals' human rights protection.

What has been just described reveals not just the question-begging capacity of the ECtHR to contribute meaningfully to human rights protection of individuals in the $\mathrm{EU}$, but it might be extended to the capacity of the judiciary as a whole. This conclusion, if merited, is all the more disquieting, as the ECtHR's limited or exceptional role in protecting human rights is to a certain extent built into its very nature. After all, the ECtHR system of judicial protection is envisaged as a subsidiary system, which requires that human rights of individuals are first effectively and comprehensively protected on the domestic level. The ECtHR can thus be seized only after all the national remedies have been exhausted.

For a satisfactory functioning of the subsidiary system of judicial protection, the role of the national courts is crucial. However, the very avalanche of cases that the ECtHR is swamped with proves that they have been unable to fulfill this task. The national ordinary courts in many European countries do not conceive of themselves obliged to protect human rights, since they are part of the materia constitutionis and hence within the jurisdictional domain of the constitutional courts. But the latter, like the ECtHR, have been similarly overburdened by individual applications and are also working hard on the filtering of cases. This involves shifting the docket problem on the reluctant ordinary courts. In short, while we are indeed deeply permeated by the culture of rights and can pride ourselves with their inflation, when the rights are violated it is hard to find an appropriate remedy in a reasonable time or sometimes even at all. It is submitted that the EU's ambition to join the ECHR has neglected and/or downplayed this point.

\subsection{EU Inflation of Human Rights in Transnational Context}

The second example which testifies to the negative effects of human rights inflation in the European Union is the notorious Kadi case. As a result of the UN mandated anti-terrorist targeted sanctions in 2001, Mr. Kadi's funds in the UK were frozen. This had been done by a judicially confirmed violation of his rights to a fair hearing, of the right to respect for property, and of the right to effective judicial review. ${ }^{37}$ All these rights have been formally protected in the legal orders of the member states, the European Union as well as in the ECHR. There was thus an inflation of

37 Case T-315/01, para. 136. 
human rights across legal orders, but they were out of Mr. Kadi's reach for almost a decade. The Member State refrained from protecting Mr. Kadi's rights since they were violated by an EU legal act for whose review it was incompetent. The EU judiciary too initially refused to grant him judicial protection, since the EU act was implementing the allegedly supreme Security Council Resolution. The latter, of course, could neither be challenged within the UN system, as there is no UN court which is competent to rule on the individual complaints. Finally, as the ECJ had finally moved to protect Mr. Kadi's rights by invalidating the contested EU regulation for its violation of EU human rights, the European Commission appealed the ruling and postponed the effectuation of the remedy further. The case was ultimately solved on political rather than legal grounds, proving the merely formal or at best ancillary status of human rights in the EU legal order. ${ }^{38}$

Once again we were faced with a situation in which a huge discrepancy between the EU human rights on the books and those in practice could be observed. This time around the discrepancy has been made patent by the involvement of a transnational context. The EU multilevel system of judicial protection, rife with human rights, appeared hapless when actual human rights of a concrete individual were affected through the mechanisms of international law. ${ }^{39}$ The scandalous handling of Mr. Kadi's case is detrimental for EU human rights protection under any scenario quoted above. It demonstrates that human rights are anything but a genuine tool for the protection of an individual. This, necessarily, detracts from the desired and required legitimating power of rights. Mr. Kadi's example engenders exactly the opposite effect. As such it, finally, undermines human rights protection on their own premises. Proliferation of human rights on the books, which is not matched with their better protection in practice, necessarily results in the decline of their value. It is yet another negative example of an inflation of human rights in the European Union.

38 See M. Avbelj, F. Fontanelli, G. Martinico (eds.), Kadi on Trial: A Multifaceted Analysis of the Kadi Trial (Routledge, 2014); M. Avbelj, D. Roth-Isigkeit, 'The UN, the EU, and the Kadi case: A new appeal for genuine institutional cooperation' (2016) 17 German Law Journal 153.

39 See M. Avbelj, 'The case of Mr Kadi and the modern concept of law' in Avbelj, Fontanelli, Martinico (eds.), Kadi on Trial: A Multifaceted Analysis of the Kadi Trial (Routledge, 2014). 


\subsection{The Inflation of Human Rights and Constitutional Backsliding in the Member State}

The last example, which contributes to the conclusion that human rights in the European Union are not better protected despite their omnipresence, is the most recent political phenomenon of constitutional backsliding in several EU member states. The roots of the phenomenon date back to Hungary, where in 2010 Victor Orban achieved a landslide victory which left him with a constitutional majority in the Hungarian parliament. ${ }^{40}$ This enabled him to embark on the constitutional reconstruction of the Hungarian state whose symbolical outcome ought to be an illiberal democracy. ${ }^{41}$ The latter, however, merely acts as a smokescreen for the total political capture of the state by a single political party in practice. In this overt hijacking of the state, human rights have again been relegated to a secondary status. They are relied upon depending on their utility, to the extent they do not stand in the way of the identified political objectives. Shall they come across as an obstacle, they will be circumvented, twisted to fit the political goals or even infringed upon.

While Hungary was first to set the process of constitutional backsliding in motion, it has since not remained an isolated case. The process, which has various guises, has in a more or less overt manner spread beyond Hungary to other member states in Central Europe. ${ }^{42} \mathrm{~A}$ trend of

40 J.-W. Müller, 'The Hungarian tragedy', (2011) Dissent 5-10; G. Halmai, K.L. Scheppele (eds.), 'Opinion on Hungary's New Constitutional Order: Amicus Brief for the Venice Commission on the Transitional Provisions of the Fundamental Law and the Key Cardinal Laws', available at: http:// lapa.princeton.edu/hosteddocs/hungary/Amicus_Cardinal_Laws_final.pdf; K. L. Scheppele, 'The Unconstitutional Constitution', New York Times (2012), available at: http://krugman.blogs.nytimes.com/2012/01/02/the-unconstitutionalconstitution/; see also a vibrant debate at Verfassungsblog: Hungary - Taking Action; available at: http://www.verfassungsblog.de/en/category/focus/hungarytaking-action/; B. Bugarič, 'Protecting Democracy and the Rule of Law in the European Union: The Hungarian Challenge', [2014] LSE 'Europe in Question' Discussion Paper Series 79: A. von Bogdandy, P. Sonnevend (eds.), Constitutional Crisis in the European Constitutional Area (Hart, 2014).

41 J.-W. Müller, 'The problem with "illiberal democracy", https://www. project-syndicate.org/commentary/the-problem-with-illiberal-democracy-by-janwerner-mueller-2016-01?barrier=accesspaylog.

42 B. Bugarič, "A crisis of constitutional democracy in Post-Communist Europe: "Lands-in-between" democracy and authoritarianism' (2015) 13 International Journal of Constitutional Law 219-245; T. Koncewicz, 'Farewell to the Polish Constitutional Court' (2016) VerfBlog http://verfassungsblog.de/farewellto-the-polish-constitutional-court/; M. Avbelj, 'Failed Democracy: The Slovenian 
reversing the at least formally adhered to constitutional standards of rule of law, democracy and human rights protection across several, mostly new EU member states, can be now identified. Despite the fact that the Union and its member states are all founded on respect for human rights and fundamental freedoms and that the latter is one of the key accession conditions that every candidate country has to meet, the political forces in several member states seized the opportunity for authoritarian entrenchment of their political power and a wholesale undermining of human rights of their more or less immediate political opponents. The EU itself has contributed to this trend by not reacting to the Hungarian developments in a timely manner.

Here too a discrepancy between the human rights on the books and those in practice can be identified. The member states have pushed for a strengthened protection of human rights in the European Union. This has, in return, invested in its own human rights build-up as well as in ensuring that new member states are fully compliant with human rights as they are to be protected in the European constitutional space lato sensu. Ten years after the big-bang enlargement and the accession of the post-communist member states to the EU, where human rights figured not just as a part of an emancipatory narrative but as a part of very tangible political battles for self-determination, these very same human rights find themselves under a serious threat of a systemic violation. Neither the domestic opposition forces, human rights actors, nor the European Union have so far been able to counter this trend successfully.

The inaction of the European Union has proven to be especially disappointing. The Treaty of Lisbon provides an explicit legal basis for sanctioning the member states' systemic violation of the EU fundamental values. The mechanisms in place are admittedly subject to burdensome procedural conditions and the sanctioning measures they can result in will not necessarily lead to a wholesale human rights improvement in the rouged member states. ${ }^{43}$ Nevertheless, a very cautious approach of the EU institutions to their actual use demonstrates an apparent lack of a political will to take human rights seriously even when rights, the rule of law and democracy are under a systemic threat. ${ }^{44}$

Patria Case - (Non)Law in Context', http://papers.ssrn.com/sol3/papers.cfm? abstract_id=2462613.

${ }_{43}$ M. Avbelj, 'Pluralism and Systemic Defiance in the European Union' in A. Jakab, D. Kochenov (eds.), The Enforcement of EU Law and Values: Ensuring Member States' Compliance (OUP, 2017).

44 After its hands-free approach to Hungary, the European Commission has addressed the situation in Poland more seriously by starting the rule of law 
As a result, the real value of human rights in the Union is again undermined. More and normatively denser human rights regimes in the European constitutional space have not brought about an improvement in actual human rights protection on the ground. To the contrary, the inflation of human rights, the fact that more rights have led to less protection, might have been one of the factors that have facilitated the overall decline in the rule of law in the European Union. If it turns out, paradoxically, that it is easy to get away from human rights violations despite the formal increase in their protection, this will only provide incentives for further violations, ultimately contributing to an inflationary spiral of human rights protection in the Union in which more rights on paper means fewer rights in practice.

\section{LOOKING FOR SOLUTIONS TO TAKE THE RIGHTS SERIOUSLY}

Provided that the above analysis of the negative consequences of human rights inflation in the European Union strikes you as persuasive, what are the possible ways of improving the situation? There are several of them, but the most important one should take place on the level of an overall attitude to human rights protection in the European Union. A switch in the perspective might be merited. The enthusiasm over multilevel system of human rights protection and related proliferation of human rights standards and institutions ought to be curbed and replaced by a more balanced approach, following which the quality of human rights protection in practice should be preferred to the quantity of human rights protection. The belief that more human rights regimes and instruments lead to better human rights protection should be superseded by an approach to human rights according to which less is more. This "less" could mean fewer human rights regimes, fewer human rights instruments or at least a different and much more precise division of labor among them. The latter conclusion certainly applies to the institutions that ought to be in charge of human rights protection.

Concretely this should lead to strengthening of the principle of subsidiarity in the field of human rights protection. Human rights should be protected as closely as possible to the actual site of their violation. This rationale is already at play in a relationship between states and

framework mechanism, which has so far nevertheless remained without any tangible implications in practice. See http://ec.europa.eu/justice/effective-justice/ rule-of-law/index_en.htm. 
ECHR, but much less between the EU and its member states. There the EU continues to have inroads into the national systems of human rights protection, not for their own sake, but to protect its constitutive principles. To prevent the competence creep and false impressions that the rights of the individuals against their member states can be in general protected on the supranational, rather than on the national level, a more circumscribed construction of the Charter's application would be welcome. At the moment all national acts, in principle, fall under the jurisdictional scope of the EU institutions, but these lack the capacity for their actual protection.

Also, human rights protection should cease to be viewed as almost an exclusive prerogative of a judicial branch. Most violations of human rights by the public authorities occur in a variety of administrative procedures. The phase of adjudication in the courts is already an ex-post, curative means for remedying the violations that have already occurred. To have fewer cases on the courts and simultaneously rights better protected, more should be invested into the preventive mechanisms. The culture of rights, to stick with a popular term, should be thus spread to the administrative branch lato sensu. Authorities of all kinds, public, hybrid and private, which exercise public powers against individuals, should develop awareness that it is them and primarily them, not the courts, which are bound by human rights protection.

Achieving this goal is, of course, anything but easy, given that in many countries not even the so-called ordinary courts, let alone the administrative organs, see themselves as called upon to protect human rights. Pursuant to statutory positivism and the entrenched traditionally limited role of the ordinary courts, human rights as constitutional standards are still seen as belonging almost exclusively to the domain of constitutional courts. However, the latter cannot shoulder the entire burden themselves. A better division of labor - shifting more responsibility for human rights protection to lower instances, closer to the actual life-world human rights occurrences - is therefore not just preferable, it is necessary.

This is not to say that the courts at the peak of judicial hierarchy have no room for improvement. To the contrary, they should strive to decide more cases on the merits, rather than just quashing the rulings of lower instances and ordering a retrial. But more importantly, they should make their case law more predictable, offering more guidance on what it means to have a particular human right. This could be achieved by less ad-hoc balancing of human rights, which produces case-specific solutions only, without painting a broader picture of what the core and the limits of a particular human right are. In more theoretical terms, but consequently also in practice, the European balancing approach could move closer to 
the American more categorical protection of human rights. This would, at least to a certain extent, entail the change in the prevalent conception of human rights. The dominant European conception of rights as principles could be replaced by a conception of rights as rules. ${ }^{45}$

Of course, opting for an alternative conception of rights, when rights as principles are so much entrenched in the European constitutional thought, is anything but likely. Nevertheless, some steps in the direction of strengthening legal certainty, legal predictability and the awareness of what one has in virtue of having a human right could be gradually made in the judicial practice. Human rights, irrespective of their exact conception, are extremely important individual and collective goods that have an intrinsic value for the rights bearing individuals and their respective polities. This intrinsic value can be lost if human rights are not taken seriously and especially when they are subject to inflation. Furthermore, the intrinsic value is not just reduced to zero, but turned into a loss for the individuals, whose rights are not meaningfully protected in practice; and for the polity, whose respective legitimacy will be in decline due to the inadequate human rights protection. The European Union and its citizens run precisely the described risk. It must be averted and this chapter's aim has been to contribute to that.

45 R. Alexy, A Theory of Constitutional Rights (OUP, 2002); see also M. Kumm, 'Constitutional rights as principles: On the structure and domain of constitutional justice. A review essay on a theory of constitutional rights by Robert Alexy', (2004) 2 International Journal of Constitutional Law 574. 